\title{
PERLINDUNGAN HUKUM BAGI DOKTER DALAM MENANGANI KEADAAN MEDIS DARURAT BERDASARKAN IMPLIED CONCENT
}

\author{
Mahsun Ismail \\ Fakultas Hukum Universitas Madura, Email : mahsunismail09@gmail.com
}

\begin{abstract}
ABSTRAK
Dokter sebagai komponen utama pemberi pelayanan kesehatan kepada masyarakat mempunyai peranan penting karena terkait langsung dengan pemberian pelayanan kesehatan dan mutu pelayanan. Oleh sebab itu, dokter dalam menangani pasien yang sedang gawat darurat harus bertindak cepat, tepat, dan bermutu untuk menolong pasien tersebut agar dapat menyelamatkan nyawa pasien dari kematian atau pun kecacatan. Maka, sebelum memberikan tindakan medis para dokter kepada pasien berdasarkan Undang-Undang Nomor 36 Tahun 2009 tentang Kesehatan, Undang-Undang Nomor 29 Tahun 2004 tentang Praktik Kedokteran, dan Peraturan Menteri Kesehatan Nomor 290/Menkes/Per/III/2008 tentang Persetujuan Tindakan Kedokteran, seorang dokter harus mendapatkan persetujuan tindakan medis dari pasiennya (informed consent), karena tanpa hal tersebut, dokter dapat dipersalahkan secara hukum atas tindakan medisnya. Secara umum persetujuan tindakan medis yang diberikan oleh pasien kepada dokter untuk melakukan tindakan medis dapat dibedakan menjadi menjadi dua bentuk, yaitu: dengan suatu pernyataan (expressed) yang meliputi persetujuan secara lisan dan persetujuan tertulis, serta persetujuan dengan isyarat (implied concent) yang meliputi dalam keadaan biasa dan dalam keadaan gawat darurat. Implied concent merupakan persetujuan tindakan medis yang diberikan pasien secara tersirat, tanpa persyaratan yang tegas, sehingga implied concent ini adalah peristiwa sehari-hari, seperti, pasien datang ke rumah sakit untuk mengetahui tekanan darah, pengambilan contoh darah, pemeriksaan badan, pemeriksaan pernapasan dengan stetoskop, pengukuran tensinya, dan sebagainya. Artinya, implied concent adalah persetujuan yang dianggap diberikan oleh pasien, umumnya diberikan dalam keadaan normal, artinya dokter menangkap persetujuan tindakan medis tersebut dari isyarat yang diberikan/dilakukan pasien. Sedangkan dalam keadaan terjadi sengketa medis antara pasien dengan dokter agar langsung diproses melalui jalur hukum, terlebih dahulu dimintakan pendapat dan mediasi dari Majelis Kehormatan Disiplin Kekdoteran Indonesia untuk menentukan ada atau tidaknya kesalahan yang dilakukan oleh dokter dalam pelaksanaan tindakan medis dan menetapkan sanksi bagi dokter yang dinyatakan bersalah.
\end{abstract}

Kata-kata kunci : Perlindungan Hukum; Dokter; Medis; Implied Concent.

\section{ABSTRACT}

Doctors as the main component of providing health services to the community have an important role because they are directly related to the provision of health services and service quality. Therefore, doctors in dealing with patients who are in emergency must act quickly, precisely, and quality to help these patients to save the lives of patients from death or disability. So, before giving medical action to doctors to patients based on Law Number 36 of 2009 concerning Health, Law Number 29 of 2004 concerning Medical Practice, and Regulation of the Minister of Health Number 290 / Menkes / Per / III / 2008 concerning Approval of Medical Measures, a 
doctor must obtain informed consent from the patient, because without this, the doctor can be blamed legally for his medical actions. In general, the agreement of medical action given by the patient to the doctor to take medical action can be divided into two forms, namely: with a statement (expressed) which includes verbal approval and written approval, as well as an implied concent agreement which includes in normal circumstances and in an emergency. Implied concent is an agreement of medical action given by the patient implicitly, without explicit requirements, so that the implied concent is everyday events, such as, patients come to the hospital to find out blood pressure, taking blood samples, body checks, breathing examinations with a stethoscope, tensile measurement, and so on. That is, implied concent is an agreement that is considered given by the patient, generally given under normal circumstances, meaning that the doctor catches the approval of the medical action from the cue given / performed by the patient. Whereas in the event of a medical dispute between the patient and the doctor so that it is directly processed through legal channels, firstly asked for an opinion and mediation from Majelis Kehormatan Disiplin Kekdoteran Indonesia (the Indonesian Standing Discipline Honorary Council) to determine whether or not a mistake was made by the doctor in carrying out medical actions and stipulating sanctions for the doctor stated guilty.

Key words: Legal Protection; Doctor; Medical; Implied Consent.

\section{PENDAHULUAN}

Kesehatan merupakan faktor terpenting dalam kehidupan manusia, karena produktivitas dan aktifitas seseorang dipengaruhi oleh kondisi kesehatan orang tersebut. Tetapi hal ini menjadi berbeda, ketika seseorang dihadapkan dengan kondisi ketika tidak dapat melakukan aktivitasnya karena sakit, dikarenakan beberapa hal seperti pola hidup tidak sehat, bencana alam, maupun kecelakaan yang tidak dapat dihindarkan. Keadaan tersebut, akan lebih mengkhawatirkan apabila seseorang berada dalam kondisi gawat darurat yang membutuhkan pertolongan medis cepat dan tepat untuk mencegah kematian maupun kecacatan. Hal tersebut dapat segera dihindari dengann adanya upaya pertolongan medis yang dilakukan oleh tenaga kesehatan yakni seseorang dokter kepada pasiennya dengan harapan pasien tersebut dapat kembali sehat. Hubungan perikatan antara dokter dengan pasien pada hakikatnya merupakan hubungan yang istimewa. Hal ini mengingat sifat dari perikatan yang dibuat antara keduanya menurut hukum hubungan antara dokter dan pasien merupakan suatu perjanjian yang objeknya berupa pelayanan medis atau upaya penyembuhan yang dikenal sebagai transaksi terapeutik (penyembuhan).

Transaksi terapeutik adalah perjanjian antara dokter dengan pasien, berupa hubungan hukum yang melahirkan hak dan kewajiban bagi kedua belah pihak berbeda dengan transaksi yang biasa dilakukan oleh masyarakat, transaksi terapeutik memiliki

sifat atau ciri yang khusus yang berbeda dengan perjanjian pada umumnya, kekhususannya terletak pada atau mengenai objek yang diperjanjikan. Objek dari perjanjian ini adalah berupa upaya atau terapi untuk penyembuhan pasien Artinya, objek 
perjanjian dalam transaksi terapeutik bukan kesembuhan pasien, melainkan mencari upaya yang tepat untuk kesembuhan pasien (Nasution, 2013: 11). Dalam konteks ini, pasien menyatakan kehendaknya untuk menceritakan riwayat penyakitnya kepada dokter dan dokter menyatakan kehendaknya untuk mendengar keluhan pasien, maka pada tahap ini telah terjadi kesepakatan antara kedua belah pihak.

Kedatangan pasien ke rumah sakit, praktik dokter, dan atau sarana pelayanan medis lainnya dapat ditafsirkan bahwa pasien bertujuan untuk mengajukan penawaran kepada dokter untuk diminta pertolongan dalam mengatasi keluhan yang dideritanya. Begitu pula sebaliknya, dokter akan melakukan pelayanan medis yang berupa rangkaian tindakan terhadap pasiennya. Oleh sebab itu, adanya transaksi terapeutik merupakan perkembangan dalam hukum perdata, yaitu masuk dalam kategori perjanjian lain sebagaimana yang diterangkan pada pasal 1319 Kitab Undang-Undang Hukum Perdata, bahwa untuk semua perjanjian baik yang mempunyai suatu nama khusus, maupun yang tidak dikenal dengan suatu nama tertentu, tunduk pada peraturan umum. Mengenai perikatan pada umumnya (Bab I Buku III Kitab Undang-Undang Hukum Perdata) dan pada peraturan umum mengenai perikatan yang bersumber pada perjanjian (Bab II Buku III Kitab Undang-Undang Hukum Perdata).

Transaksi terapeutik seorang dokter mengupayakan kesembuhan pasien melalui pencarian, terapi yang paling tepat berdasarkan ilmu pengetahuan yang dimilikinya dan pasien berkewajiban secara jujur menyampaikan apa yang dikeluhkannya agar dapat ditemukan beberapa alternatif pilihan terapi untuk akhirnya pasien berhak memilih jenis terapi yang diinginkan berdasarkan informasi yang diberikan oleh dokter. Maka, perjanjian adalah suatu peristiwa bahwa seseorang berjanji kepada orang lain atau antara dua orang yang saling berjanji untuk melaksanakan sesuatu hal. Untuk sahnya suatu perjanjian menurut Agus Yuda Hermoko (2011: 157) harus memenuhi syarat sebagaimana diatur dalam Pasal 1320 Kitab Undang-Undang Hukum Perdata yang unsur-unsurnya yakni: sepakat mereka yang mengikatkan dirinya (toesteming van degeneng die zich verbinden), kecakapan untuk membuat perikatan (debekwaamheid om eene verbintenis aan te gaan), suatu hal tertentu (een bepaald onderewerp), dan suatu sebab yang halal atau diperbolehkan (eene geoorloofdeoorzaak).

Secara yuridis suatu transaksi terapeutik termasuk jenis perjanjian upaya (inspanningsverbintenis), karena seorang dokter tidak menjamin akan keberhasilan usaha penyembuhan, maka sewaktu mengadakan pembicaraan dengan pasien, dokter harus berhati-hati dan jangan memberikan jaminan akan pasti berhasil tindakan atau pasti akan sembuh penyakitnya. Karena dengan mengutarakan hal yang demikian, transaksi terapeutik itu secara yuridis akan beralih dari suatu (inspanningverbintenis) menjadi suatu (resultaatsverbintenis). Dalam hukum perikatan sebagaimana diatur 
dalam Kitab Undang-Undang Hukum Perdata, dikenal adanya dua macam perjanjian, yaitu: pertama, inspanningsverbintenis, yaitu perjanjian upaya, artinya kedua belah pihak yang berjanji berdaya upaya secara maksimal untuk mewujudkan apa yang diperjanjikan. Kedua, resultaatverbintenis, yakni suatu perjanjian bahwa pihak berjanji akan memberikan suatu resultaat, yaitu suatu hasil yang nyata sesuai dengan apa yang diperjanjikan (Nasution, 2013: 13).

Dokter sebagai salah satu komponen utama pemberi pelayanan kesehatan kepada masyarakat mempunyai peranan yang sangat penting karena terkait langsung dengan pemberian pelayanan kesehatan dan mutu pelayanan yang diberikan. Landasan bagi dokter untuk melaksanakan tindakan medis terhadap orang lain adalah ilmu pengetahuan, teknologi, serta kompetensi yang dimiliki dan diperoleh melalui pendidikan, dan pelatihan. Setiap upaya pelayanan kesehatan hasilnya tidak selalu memuaskan semua pihak terutama pasien, yang pada gilirannya dengan mudah menimpakan beban kepada dokter bahwa telah terjadi malpraktek. Tingginya tuntutan masyarakat akan mutu pelayanan kesehatan sering kali menimbulkan ketidakpuasan masyarakat terhadap pelayanan kesehatan yang diberikan. Hal ini menyebabkan masyarakat menuduh dokter telah melakukan malpraltek atau kelalaian dalam melakukan tindakan medis. Dokter sebagai anggota profesi yang mengabdikan ilmunya pada kepentingan umum, mempunyai kebebasan serta kemandirian yang berorientasi pada nilai-nilai kemanusiaan dibawah panji kode etik kedokteran. Adanya kode etik kedokteran ini bertujuan untuk mengutamakan kepentingan dan keselamatan pasien, menjamin bahwa profesi kedokteran harus senantiasa dilaksanakan dengan niat yang luhur dan dengan cara yang benar.

Untuk memenuhi hak pasien untuk mendapatkan pelayanan kesehatan, setiap pelaksanaan tindakan medis harus sesuai dengan standar profesi kedokteran yang meliputi pengetahuan (knowledge), keterampilan (skill), perilaku yang profesonal (profesional attitude). Karena setiap kelalaian, kecelakaan, atau bentuk kesalahan lain yang timbul dalam pelaksanaan tindakan medis itu tetap bisa menyebabkakn pasien merasa tidak puas dan berpotensi untuk mengajukan tuntutan hukum. Sebab dokter dalam melaksanakan tindakan medis harus sesuai dengan apa yang disebut dengan standar profesi dan standar operasional prosedur. Setiap dokter melakukan tindakan medis terhadap pasien, dokter berkewajiban untuk memberikan informasi tentang jenis penyakit yang diderita pasien dan tindakan medis yang akan dilakukan untuk menyelamatkan jiwa pasien serta risiko-risiko yang mungkin timbuldari tindakan medis tersebut kepada pasien dan keluarganya. Bentuk persetujuan yang diberikan oleh pasien atau keluarganya terhadap tindakan medis yang akan dilakukan oleh dokter biasa disebut dengan informed concent. Pelaksanaan hak atas persetujuan tindakan medis 
(informed concent) atas informasi kepada pasien atau keluarganya telah tercantum dalam ketentuan yang berbunyi : "Setiap orang berhak untuk mendapatkan informasi dan edukasi tentang kesehatan yang seimbang dan bertanggung jawab"(Undang-Undang Nomor 36 Tahun 2009 tentang Kesehatan pada Pasal 7). Serta," Semua tindakan kedokteran yang akan dilakukan terhadap pasien harus mendapat persetujuan"(Peraturan Menteri Kesehatan Nomor 290/Menkes/Per/III/2008 pada Pasal 2 ayat (1)).

Jasa tindakan medis dokter harus menyadari bahwa informed concent benar-benar dapat menjamin terlaksananya hubungan hukum antara pihak pasien dengan dokter, atas dasar saling memenuhi hak dan kewajiban masing-masing pihak yang seimbang dan dapat dipertanggung jawabkan. Berbeda halnya jika kondisi pasien yang emergensi/gawat darurat, tindakan prioritas dokter ialah menyelamatkan nyawa pasien, karena dokter berpacu dengan maut dan untuk itu ia tidak sempat untuk menjelaskan tindakan medisnya kepada pihak pasien. Dengan kondisi seperti itu pasien juga tidak sempat untuk memberikan persetujuan kepada dokter perihal tindakan medis yang akan diberikan kepadanya. Penanganan medis tanpa adanya persetujuan tertulis (informed concent) dari pasien ini biasa disebut dengan implied concent atau persetujuan yang sudah dianggap telah diberikan/tersirat.

Salah satu contoh kasus terkait dengan tindakan medis darurat terhadap pasien gawat darurat adalah kasus yang menimpa dokter Dewa Ayu Sasiary Prawan yang merupakan dokter spesialis kebidanan dan dua orang temannya. Hal ini berawal dari tuduhan pihak keluarga korban yakni, Julia Fransiska Makatey (25) yang meninggal dunia sesaat setelah melakukan operasi kelahiran anak pada tahun 2010. Akibat dari kasus tersebut dokter ayu dan kedua temannya divonis oleh Mahkamah Agung dengan hukuman 10 bulan penjara. Sedangkan kasus kedua kasus kedua Mahkamah Agung (MA) menolak kasasi Jaksa atas kasus malpraktik dengan terdakwa dr. Wida Parama Astiti dalam kasus ini MA memutuskan dr. Wida Parama Astiti telah melakukan malpraktik, sehingga pasien berusia 3 tahun meninggal dunia dan dijatuhi 10 bulan penjara.

\section{PEMBAHASAN}

Hukum merupakan sarana untuk mengatur, menertibkan, dan menyelesaikan berbagai permasalahan ditengah-tengah masyarkat disamping sarana dan pranata sosialnya. Memandang fungsi hukum dari tiga hal pokok, yaitu: berfungsi menjaga keamanan masyarakat, berfungsi menjalankan (menerapkan) ketertiban peraturan perundang-undangan serta berfungsi menyelesaikan sengketa. Oleh karena itu berfungsinya hukum banyak tergantung dan dipengaruhi sistem sosial budaya lainnya, yaitu ekonomi, sosial, budaya, kebiasaan (adat), pengetahuan dan pendidikan, agama, lingkungan, politik, dan sebagainya. 
Dokter dalam menangani pasien yang sedang gawat darurat harus bertindak cepat, tepat, dan bermutu untuk menolong pasien tersebut agar dapat menyelamatkan nyawa pasien dari kematian atau pun kecacatan. Sebelum memberikan tindakan medis kepada pasien tersebut, berdasarkan Undang-Undang Nomor 36 Tahun 2009 tentang Kesehatan, Undang-Undang Nomor 29 Tahun 2004 tentang Praktik Kedokteran, dan Peraturan Menteri Kesehatan Nomor 290/Menkes/Per/III/2008 tentang Persetujuan Tindakan Kedokteran, seorang dokter harus mendapatkan persetujuan tindakan medik dari pasiennya (informed consent), karena tanpa itu dokter dapat dipersalahkan secara hukum atas tindakan medisnya. Secara Umum persetujuan tindakan medis yang diberikan oleh pengguna jasa tindakan medis (pasien) kepada pihak pelaksana jasa tindakan medis (dokter) untuk melakukan tindakan medis dapat dibedakan menjadi menjadi dua bentuk, yaitu : pertama, dengan suatu pernyataan (expressed) yang meliputi persetujuan secara lisan dan persetujuan tertulis. Kedua, persetujuan dengan isyarat (implied concent) yang meliputi dalam keadaan biasa dan dalam keadaan gawat darurat.

Implied concent merupakan persetujuan tindakan medis yang diberikan pasien secara tersirat, tanpa persyaratan yang tegas, sehingga implied concent ini adalah peristiwa sehari-hari. Misalnya, seorang pasien datang ke rumah sakit atau fasilitas pelayanan kesehatan untuk mengukur tekanan darah, pengambilan contoh darah, pemeriksaan badan, pemeriksaan pernapasan dengan stetoskop, pengukuran tensinya, pengambilan darah di laboratorium, dan sebagainya (Guwandi, 2005: 38). Artinya, implied concent adalah persetujuan yang dianggap diberikan oleh pasien, umumnya diberikan dalam keadaan normal, artinya dokter menangkap persetujuan tindakan medis tersebut dari isyarat yang diberikan/dilakukan pasien.

Ada pula implied concent dalam bentuk lain, yaitu bila pasien dalam keadaan gawat darurat (emergency) sedangkan dokter memerlukan tindakan segera, sementara pasien dalam keadaan tidak bisa memberikan persetujuan atau tidak sadar dan keluarganya pun tidak ada di tempat dan apabila terjadi penundaan terhadap tindakan medis akan berakibat fatal terhadap jiwa pasien. Dalam situasi seperti itu, penundaan tindakan medis hanya karena menunggu persetujuan dan kemudian berakibat fatal, hal ini bisa dijadikan dasar untuk mempersalahkan dokter karena kelalaian. Maka, dokter dapat melakukan tindakan medis terbaik menurut dokter. Dalam keadaan gawat darurat atau pasien tidak sadar untuk memberikan persetujuan medis kepada dokter untuk menangani kondisinya, maka dalam kondisi seperti ini dokter langsung melakukan apa yang disebut dengan zaakwaarneming yaitu hubungan hukum yang timbul bukan karena adanya persetujaun tindakan medis terlebih dahulu, melainkan karena keadaan memaksa atau keadaan darurat, hal tersebut di atur dalam (Kitab Undang-Undang 
Hukum Perdata Pasal 1354) yang menerangkan bahwa :

Jika seseorang dengan sukarela tanpa ditugaskan, mewakili urusan orang lain, dengan atau tanpa setahu orang itu, maka ia secara diam-diam mengikatkan dirinya untuk meneruskan serta menyelesaikan urusan itu, hingga orang yang ia wakili kepentingannya dapat mengerjakan sendiri urusan itu, ia harus membebani diri dengan segala sesuatu yang termasuk urusan itu. Ia juga harus menjalankan segala kewajiban yang harus ia pikul jika ia menerima kekuasaan yang dinyatakan secara tegas

Berdasarkan atas perseoalan tidak adanya persetujuan tindakan medis yang diberikan oleh pihak pasien ataupun keluarganya maka seorang dokter diharuskan mencatat setiap tindakan yang dilakukan kepada pasien dalam rekam medis yang berisikan catatan dan dokumen tentang idenditas pasien, pemeriksaan, pengobatan, tindakan dan pelayanan lain yang telah diberikan kepada pasien. Dalam Peraturan Menteri Kesehatan Nomor. 269/Menkes/Per/III/2008 Tentang Rekam Medis pasal 3 ayat (3) menerangkan juga isi rekam medis untuk pasien gawat darurat, sekurang-kurangnya memuat 12 hal yakni : idenditas pasien, kondisi saat pasien tiba di sarana pelayanan kesehatan, idenditas pengantar pasien, tanggal dan waktu, hasil anamnesis, mencakup sekurang-kurangnya keluhan dan riwayat penyakit, hasil pemeriksaan fisik dan penunjang medik, diagnosis, pengobatan dan/atau tindakan,ringkasan kondisi pasien sebelum meninggalkan pelayanan unit gawat darurat dan rencana tindak lanjut, nama dan tanda tangan dokter, dokter gigi, atau tenaga kesehatan tertentu yang memberikan pelayanan kesehatan, sarana transportasi yang digunakan bagi pasien yang akan dipindahkan ke sarana pelayanan kesehatan lain; dan pelayanan lain yang telah diberikan kepada pasien.

Menurut Peraturan Menteri Kesehatan Nomor 290/Menkes/Per/III/2008 tentang Persetujuan Tindakan kedokteran Pasal 4 menyebutkan tiga hal yakni : pertama, dalam keadaan gawat darurat, untuk menyelamatkan jiwa pasien dan/atau untuk mencegah kecacatan tidak diperlukan persetujuan tindakan kedokteran. Kedua, keputusan untuk melakukan tindakan kedokteran sebagaimana dimaksud pada ayat (1) diputuskan oleh dokter atau dokter gigi dan dicatat dalam rekam medis. Ketiga, dalam hal dilakukannya tindakan kedokteran sebagaimana yang dimaksud pada ayat (1) dokter atau dokter gigi wajib memberikan penjelasan sesegera mungkin kepada pasien setelah pasien sadar atau kepada keluarga terdekat. Berdasarkan uraian di atas, tidak semua persetujaun tindakan medis itu harus dilakukan secara tertulis dan tidak pula harus setiap kali memerlukan informasi panjang lebar. Oleh karena itu di dalam pengertian hukum, persetujuan dapat bersifat implied concent (tersirat) dan dapat pula express(secara lisan). Seseorang yang atas kemauannya sendiri memasuki ruang periksa, kemudian juga bersedia membuka baju untuk diperiksa atau mengulurkan 
bagian tubuhnya untuk disuntik, dianggap secara tersirat (implied) sudah memberikan persetujuannya. Adapun express concent adalah persetujuan yang secara nyata diungkapkan oleh pasien, baik lisan maupun tertulis.

Sementara dalam sudut pandang pemberian persetujuan tindakan kedokteran diberikan oleh individu yang kompeten atau cakap. Bila ditinjau dari segi usia, maka seseorang dianggap kompeten atau cakap apabila telah berusia 18 tahun atau lebih dan atau telah menikah. Dalam hal pasien belum dewasa atau tidak cakap bertindak dalam lalu lintas hukum, maka yang berhak menyetujui dan/atau menolak persetetujuan tindakan medis orang tua atau walinya. Dalam Kitab Undang-Undang Hukum Perdata disebutkan bahwa seseorang yang berumur 21 tahun atau lebih atau telah menikah dianggap sebagai orang dewasa dan oleh karenanya dapat melakukan perbuatan hukum yakni bisa memberikan persetujuan. Sementara dalam Undang-Undang Nomor 23 Tahun 2002 tentang Perlindungan Anak, setiap orang yang berusia 18 tahun atau lebih dianggap sebagai orang yang sudah bukan anak-anak. Dengan demikian mereka dapat diperlakukakan sebagaimana orang dewasa yang kompeten dan oleh karenanya dapat memberikan persetujuan. Sedangkan dalam Pasal 1320 Kitab Undang-Undang Hukum Perdata tentang syarat sahnya perjanjian harus memenuhi empat hal yakni : pertama. kesepakatan mereka yang mengikatkan dirinya, kedua, kecakapan untuk membuat suatu perikatan, ketiga, suatu pokok persoalan tertentu, keempat, suatu sebab yang tidak terlarang.

Dokter dalam melakukan tindakan medis terhadap pasien, dokter berkewajiban untuk memberikan informasi tentang jenis penyakit yang diderita oleh pasien dan tindakan medis yang akan dilakukan untuk menyelamatkan jiwa pasien serta risiko yang mungkin timbul dari tindakan medis tersebut kepada pasien dan keluarganya. Penjelasan dokter diberikan dengan bahasa dan kata-kata yang dapat dipahami oleh pasien sesuai dengan tingkat pendidikan dan kematangannya, serta situasi emosional. Dokter harus berusaha mengecek apakah penjelasannya memang dipahami dan diterima pasien. Jika belum, dokter harus mengulangi lagi penjelasannya sampai pasien memahami benar. Dokter tidak boleh berusaha mempengaruhi atau mengarahkan pasien untuk menerima dan menyetujui tindakan medis yang akan dilakukan terhadap pasien. Namun jika seorang dokter menghadapi pasien yang berada dalam keadaan gawat darurat (emergency) berdasarkan Permenkes Nomor 585/1989 Pasal 11 maka " seseorang pasien yang berada dalam keadaan tidak sadar atau pingsan dan tidak didampingi keluarga terdekat dan secara medis berada dalam keadaan gawat darurat yang memerlukan diambilnya tindakan medis segera untuk kepentingannya, maka tidak diperlukan persetujuannya dari siapapun". Dimaksudkan dalam Pasal ini bahwa untuk menyelamatkan nyawa atau anggota tubuh pasien yang 
tidak sadar dan tidak ada waktu lagi untuk menunggu dan menghubungi anggota keluarganya, maka kepada dokter diberi wewenang untuk segera dan secara langsung melakukan tindakan operasinya. Tidak usah menunda-nunda lagi karena belum ada persetujuannya. Bahkan jika tidak diberikan pertolongan dan segera diambil tindakan operasi, dokter tersebut bisa dituntut berdasarkan kelalaian (negligence) atau penelantaran (abandoment), kalau sampai mengakibatkan meninggalnya pasien tersebut (Guwandi, 2005: 39-40).

Gawat darurat adalah suatu keadaan yang serius yang harus mendapatkan pertolongan segera. Bila terlambat atau terlantar akan berakibat buruk, baik memburuknya penyakit atau kematian (Yulianingsih, 2009: 6).Gawat daruat adalah suatu kondisi klinik yang memerlukan pelayanan medis. Gawat darurat medis adalah suatu kondisi yang dalam pandangan penderita, keluarga atau siapapun yang bertanggung jawab dalam membawa penderita kerumah sakit, memerlukan pelayanan segera (Notoatmodjo, 2010: 164). Undang-Undang Nomor 44 Tahun 2009 Tentang Rumah Sakit dalam Pasal 1 menerangkan bahwa gawat darurat adalah keadaan klinis pasien yang membutuhkan tindakan medis segera guna penyelamatan nyawa dan pencegahan kecacatan lebih lanjut. Upaya pelayanan dan penanggulangan pada pasien gawat darurat pada dasarnya mencakup suatu rangkaian kegiatan yang harus dikembangkan sedemikian rupa sehingga mampu mencegah kecacatan atau kematian yang mungkin terjadi. Adapun tujuan penanggulangan gawat darurat yakni: pertama, pertama, mencegah kematian dan cacat pada pasien gawat darurat, hingga dapat hidup dan berfungsi kembali dalam masyarakat. Kedua, merujuk pasien gawat darurat melaluui sistem rujukan untuk memperoleh penanganan yang lebih memadai. Ketiga, penanggulangan korban bencana (Krisanty, 2013: 1).

Keadaan pasien gawat darurat perlu adanya suatu cara untuk memilah tingkat keseriusan penyakit yang dialami pasien, untuk itu dikenal suatu cara yang biasa disebut dengan konsep dasar triage. Triage adalah konsep dasar pengkajian yang cepat dan terfokus dengan suatu cara yang memungkinkan pemanfaatan sumber daya manusia, peralatan serta fasilitas yang paling efisien dengan tujuan untuk memilih atau menggolongkan semua pasien yang memerlukan pertolongan dan menetapkan prioritas penanganannya. Klasifiksi pasien dalam sistem triase meliputi tiga macam yakni : gawat darurat, gawat tidak darurat, dan darurat tidak gawat (Krisanty, 2013: 18). Upaya pelayanan kesehatan yang bersifat penyembuhan dan pemulihan kesehatan pasien, pemerintah mendirikan dan menyelenggarakan rumah sakit pemerintah dan mengatur, membimbing, membantu dan mengawasi rumah sakit yang didirikan dan diselenggarakan oleh badan swasta. Sementara itu dokter sebagai bagian yang tidak terpisahkan dengan rumah sakit memiliki hak untuk memperoleh perlindungan hukum 
dalam melaksanakan tugas sesuai dengan profesinya. Hal ini selaras dengan ketentuan Undang-Undang Nomor 36 Tahun 2009 Tentang Kesehatan Pasal 27 ayat (1) yang menyebutkan bahwa "tenaga kesehatan berhak mendapatkan imbalan dan perlindungan hukum dalam melaksanakan tugas sesuai dengan profesinya”. Serta Undang-Undang Nomor 36 Tahun 2014 tentang Tenaga Kesehatan Pasal 75 menyatakan bahwa "tenaga kesehatan dalam menjalankan praktik berhak mendapatkan perlindungan hukum sesuai dengan ketentuan Peraturan PerundangUndangan". Artinya, hukum sebagai norma mempunyai ciri kekhususan, yaitu hendak melindungi, mengatur, dan memberikan keseimbangan dalam menjaga kepentingan umum. Pelanggaran ketentuan hukum dalam arti merugikan, melalaikan atau mengganggu keseimbangan kepentingan umum dapat menimbulkan reaksi dari masyarakat (Djamali, 2012: 3).

Upaya melindungi atu menjaga kesehatan dipengaruhi oleh faktor lingkungan sosial budaya, termasuk ekonomi, lingkungan fisik dan biologis yang bersifat dinamis dan kompleks. Menyadari betapa luasnya hal tersebut, pemerintah melalui sistem kesehatan nasional, berupaya menyelenggarakan kesehatan yang bersifat menyeluruh, terpadu, merata, dan dapat diterima serta terjangkau oleh seluruh lapisan masyarakat. Upaya tersebut diselenggarakan dengan menitikberatkan pada pelayanan kesehatan untuk masyarakat luas, guna mencapai derajat kesehatan yang optimal (Nasution, 2013: 2). Dokter memiliki profesi yang istimewa karena seorang dokter berhadapan dengan begitu banyak segi-segi kehidupan manusia. Tidak semua orang yang menjalankan tugas atau pekerjaan didalam suatu institusi atau lembaga baik di pemerintah maupun swasta itu memperoleh pengakuan sebagai profesi.

Suatu profesi menurut Soekidjo Notoatmodjo (2010: 36) sekurang-kurangnya mempunyai ciri sebagai berikut: pertama. mengikuti pendidikan sesuai standar nasional, artinya orang yang termasuk dalam profesi yang bersangkutan harus telah menyelasaikan pendidikan profesi tersebut. Orang yang berprofesi dokter, dengan sendirinya harus telah lulus pendidikan profesi dokter (bukan hanya sarjana dokter). Kedua, pekerjaannya berdasarkan etik profesi. Artinya, dalam menjalankan tugas atau profesinya seseorang harus berlandaskan atau mengacu kepada etika profesi yang telah dirumuskan oleh organisasi profesinya. Ketiga, mengutamakan panggilan kemanusiaan daripada keuntuntungan materi. Dalam menjalankan tugasnya tidak didasarkan pada keuntungan materi semata-mata. Tetapi harus mengutamakan terlebih dahulu panggilan kemanusiaan. Seorang petugas kesehatan dalam menolong penderita atau korban, yang didahulukan adalah menyelamatkan pasien atau korban, yang didahulukan adalah menyelamatkan pasien atau korban, bukan berpikir siapa yang akan membayar jasanya nanti. Keempat, pekerjaannya legal (melalui perizinan). Untuk 
menjalankan tugas atau praktik, profesi ini dituntuk perizinan secara hukum, atau izin praktik. Dokter praktik, notaris praktik, akuntan praktik, harus terlebih dahulu memperoleh izin praktik dari yang berwenang. Kelima, anggota-anggotanya belajar sepanjang hayat, seorang anggota profesi mempunyai kewajiban untuk selalu meningkatkan profesinya melalui belajar terus menerus. Seorang profesional tidak boleh berhenti belajar untuk memelihara dan meningkatkan profesionalitasnya. Keenam, anggota-anggotanya bergabung dalam suatu organisasi profesi. Seseorang yang sudah memperoleh pengakuan profesi, atau lulus dari pendidikan profesi diwajibkan untuk menjadi anggota organisasi profesi yang bersangkutan. Seseorang yang sudah lulus pendidikan dokter harus menjadi anggota Ikatan Dokter Indonesia (IDI), seseorang yang sudah lulus pendidikan Notariat, harus menjadi anggota organisasi profesi notaris.

Dokter yang telah melaksanakan praktek kedokterannya sesuai dengan standar yang berlaku, meski dalam kenyataannya terdapat tuntutan secara hukum dan bahkan dipenjarakan. Hal ini terjadi pada kasus dokter Ayu dan dokter Setyaningrum yang dituntut karena diduga melakukan malpraktek. Undang-Undang Nomor 29 Tahun 2004 tentang Praktik Kedokteran yang diharapkan dapat melindungi dan memberikan kepastian hukum, ternyata masih memiliki kekurangan dan dihapusnya Pasal-Pasal ancaman pidana pada Undang-Undang tersebut oleh Mahkamah Konstitusi menyebabkan digunakannya Pasal-Pasal dalam Kitab Undang-Undang Hukum Pidana untuk menjerat dokter-dokter yang diduga melakukan malpraktek.

Penyelesaian kasus malpraktek seringkali dibawa ke Pengadilan, meski masih terdapat pertanyaan: apakah Pengadilan mampu membuktikan kebenaran di bidang medis. Sekalipun dokter atau tenaga medis yang menjadi saksi ahli, apakah hakim bisa mengerti tentang pendapat dunia kedokteran. Maka, idealnya penyelesaian sengketa medis terlebih dahulu melalui mediasi ataupun dilaporkan ke lembaga yang berwenang untuk mempertimbangkan pelanggaran disiplin kedokteran yaitu Majelis Kehormatan Disiplin Kedokteran Indonesia (MKDKI). Maka, untuk mengindari berbagai tuntutan atas profesi medis yang dilakuka oleh seorang dokter, terdapat beberapa hal yang harus dilakukan dokter untuk menghindarkan diri dari tuntutan hukum oleh pihak pasien yakni : pertama, informed concent. Dalam menjalankankan profesinya Informed Consent merupakan kewajiban yang harus dipenuhi oleh seorang dokter. Sedangkan dalam keadaan pasien gawat darurat informed concent sudah tidak lagi diperlukan karena yang menjadi prioritas adalah penyelamatan jiwa pasien. Dalam hal dilakukannya tindakan kedokteran tanpa adanya informed concent dokter wajib memberikan penjelasan sesegera mungkin kepada pasien setelah pasien sadar atau kepada keluarga terdekat. Kedua, rekam medis. Pengaturan rekam medis terdapat 
dalam Undang-Undang Nomor 29 Tahun 2004 Tentang Praktik KedokteranPasal 46 ayat (1). Rekam medis merupakan berkas yang berisi catatan dan dokumen tentang identitas pasien, pemeriksaan, pengobatan, tindakan dan pelayanan yang diberikan kepada pasien. Rekam medis dibuat dengan berbagai manfaat, yaitu untuk pengobatan pasien, peningkatan kualitas pelayanan, pendidikan dan penelitian, pembiayaan, statistik kesehatan serta pembuktian masalah hukum, disiplin dan etik. Ketiga, volenti non fit iniura atau asumption of risk yakni doktrin lama dalam ilmu hukum yang diterapkan pada hukum kesehatan, yaitu suatu asumsi yang sudah diketahui sebelumnya tentang adanya resiko medis yang tinggi pada pasien apabila dilakukan suatu tindakan medis padanya. Apabila telah dilakukan penjelasan selengkapnya dari dokter dan ternyata pasien atau keluarga setuju (informed consent), apabila terjadi resiko yang telah diduga sebelumnya, maka dokter tidak dapat dipertanggungjawabkan atas tindakan medisnya. Selain itu doktrin ini dapat juga diterapkan pada kasus pulang paksa (pulang atas kehendak sendiri walaupun dokter belum mengizinkan), maka hal semacam itu membebaskandokter dan rumah sakit dari tuntutan hukum. Keempat. res ipsa loquitur yakni berkaitan secara langsung dengan beban pembuktian (onus, burden of proof), yaitu pemindahan beban pembuktian dari penggugat (pasien atau keluarganya) kepada tergugat (tenaga medis). Terhadap kelalaian tertentu yang sudah nyata, jelas sehingga dapat diketahui seorang awam atau menurut pengetahuan umum antara orang awam atau profesi medis atau kedua-duanya, bahwa cacat, luka, cedera atau fakta sudah jelas nyata dari akibat kelalaian tindakan medik dan hal semacam ini tidak memerlukan pembuktian dari penggugat akan tetapi tergugatlah yang harus membuktikan bahwa tindakannya tidak masuk kategori lalai atau keliru.

Mahkamah Agung melalui Surat Edarannya (SEMA) tahun 1982 telah memberikan arahan kepada para Hakim, bahwa penanganan terhadap kasus dokter atau tenaga kesehatan lainnya yang diduga melakukan kelalaian atau kesalahan dalam melakukan tindakan atau pelayanan medis agar jangan langsung diproses melalui jalur hukum, tetapi dimintakan dulu pendapat dari Majelis Kehormatan Etik Kedokteran (MKEK). Namun, kini MKEK fungsinya digantikan oleh Majelis Kehormatan Disiplin Kedokteran Indonesia (MKDKI) suatu lembaga independen yang berada dibawah Konsil Kedokteran Indonesia (KKI). Mediasi dalam Kamus Besar Bahasa Indonesia mengandung arti sebagai proses pengikutsertaan pihak ketiga dalam penyelesaian suatu perselisihan sebagai penasehat. Oleh sebab itu, pengertian mediasi yang diberikan Kamus Besar Bahasa Indonesia mengandung tiga unsur penting. Pertama, mediasi merupakan proses penyelesaian perselisihan atau sengketa yang terjadi antar dua pihak atau lebih. Keedua, pihak yang terlibat dalam penyelesaian sengketa adalah pihak-pihak yang berasal dari luar pihak yang bersengketa. Ketiga, pihak yang terlibat dalam penyelesaian sengketa tersebut bertindak sebagai penasihat dan tidak 
memiliki kewenangan apa-apa dalam pengambilan keputusan (Abbas, 2011: 2-3).

Mediasi merupakan salah satu bentuk dari alternatif penyelesaian sengketa di luar Pengadilan. Mediasi mengantarkan para pihak pada perwujudan mengingat penyelesaian sengketa melalui mediasi yang menempatkan kedua belah pihak pada posisi yang sama, tidak ada pihak yang dimenangkan atau pihak yang dikalahkan (win-win solution). Mediasi dapat memberikan sejumlah keuntungan bagi dokter ataupun dari pihak pasien, menurut Syahrizal Abbas (2011: 5-26) terdapat keuntungan mediasi, yakni: pertama, mediasi diharapkan dapat menyelesaikan sengketa secara cepat dan relatif murah dibandingkan dengan membawa perselisihan tersebut ke Pengadilan atau kelembaga Arbitrase. Kedua, mediasi akan memfokuskan perhatian para pihak pada kepentingan mereka secara nyata dan pada kebutuhan emosi atau psikologis mereka, sehingga mediasi bukan hanya tertuju pada hak-hak hukumnya. Ketiga, mediasi memberikan kesempatan para pihak untuk berpartisipasi secara langsung dan secara informal dalam menyelesaikan perselisihan mereka. Keempat, mediasi memberikan para pihak kemampuan untuk melakukan kontrol terhadap proses dan hasilnya. Kelima, mediasi dapat mengubah hasil, yang dalam litigasi dan arbitrase sulit diprediksi, dengan suatu kepastian melalui suatu konsensus. Keenam, mediasi memberikan hasil yang tahan uji dan akan mampu menciptakan saling pengertian yang lebih baik diantara para pihak yang bersengketa karena mereka sendiri yang memutuskannya. Ketujuh, mediasi mampu menghilangkan konflik atau permusuhan yang hampir selalu mengiringi setiap putusan yang bersifat memaksa yang dijatuhkan oleh hakim di Pengadilan atau arbiter pada lembaga Arbitrse.

Undang-Undang Praktik Kedokteran Nomor 29 Tahun 2004 tentang Praktik Kedokteran mengamanatkan terbentuknya lembaga penyelesaian disiplin dokter yang kemudian dikenal dengan Majelis Kehormatan Disiplin Kedokteran Indonesia (MKDKI). Majelis Kehormatan Disiplin Kedokteran Indonesia bukan lembaga mediasi, dalam konteks mediasi penyelesaian sengketa, namun Majelis Kehormatan Disiplin Kedokteran Indonesia adalah lembaga Negara yang berwenang untuk menentukan ada atau tidaknya kesalahan yang dilakukan dokter.

\section{PENUTUP}

Implied concent merupakan persetujuan tindakan medis yang diberikan pasien secara tersirat, tanpa persyaratan yang tegas, sehingga implied concent ini adalah peristiwa sehari-hari. Misalnya, seorang pasien datang ke rumah sakit atau fasilitas pelayanan kesehatan untuk mengukur tekanan darah, pengambilan contoh darah, pemeriksaan badan, pemeriksaan pernapasan dengan stetoskop, pengukuran tensinya, pengambilan darah di laboratorium, dan sebagainya. Bahwa dokter dalam melakukan 
tindakan kedokteran harus meminta persetujuan dari pasien, namun dalam keadaan pasien tidak sadar atau gawat darurat dan keluarganya pun tidak ada di tempat, sedangkan dokter memerlukan tindakan segera untuk menyelamatkan jiwa pasien, maka persetujuan tindakan medis tidak diperlukan. Dalam keadaan gawat darurat pasien diklasifikasikan dalam tiga bentuk diantaranya, pasien gawat darurat, pasien gawat tidak darurat, pasien darurat tidak gawat.

Dokter melakukan tugas profesinya berhak mendapatkan perlindungan hukum sepanjang memenuhi standar profesi dan standar prosedur operasional. Selanjutnya, dokter memiliki hak untuk menolak tindakan medis yang bertentangan dengan kode etik profesinya, hak untuk memilih pasien dan mengakhiri hubungan profesional dengan pasien, dan hak atas imbalan jasa. Selain itu dokter berkewajiban untuk bekerja sesuai dengan standar profesi dan standar operasional prosedur, memberikan informasi tentang tindakan medis yang akan dilakukan terhadap pasien, dan kewajiban untuk menyimpan rahasia pekerjaannya. Bahwa dalam keadaan terjadi sengketa medis antara pasien dengan dokter agar jangan langsung diproses melalui jalur hukum akan tetapi dimintakan terlebih dahulu pendapat dari Majelis Kehormatan Disiplin Kekdoteran Indonesia untuk menentukan ada atau tidaknya kesalahan yang dilakukan oleh dokter dalam pelaksanaan tindakan medis dan menetapkan sanksi bagi dokter yang dinyatakan bersalah.

\section{DAFTAR PUSTAKA}

Anik Maryunani, Yulianingsih, 2009, Asuhan Kegawatdaruratan Dalam Kebidanan, Jakarta, Trans Info Media.

Agus Yudha Hernoko, 2011, Hukum Perjanjian Asas Proporsionalitas Dalam Kontrak Komersial, Jakarta, Kencana

Burhan Ashshofa, 2013, Metode Penelitian Hukum, Jakarta, Rineka Cipta

Bahder Johan Nasution, 2013, Hukum Kesehatan Pertanggung Jawaban Dokter, Jakarta, Rineka Cipta.

Cholid Narbuko dan H. Abu Achmadi, 2009, Metodologi Penelitian, Jakarta, Bumi Aksara.

Robert Priharjo, 2008, Konsep \& Perspektif Praktik Keperawatan Profesional, Jakarta, Buku Kedokteran EGC

R. Abdoel Djamali, 2012, Pengantar Hukum Indonesia, Jakarta, Rajawali Pers.

Hadi Siswanto, Heru Subaris Kasjono, Mardjan Mantariputra, 2010, Etika Profesi Sanitariatan dan Pembangunan Berwawasan Kesehatan, Yogyakarta, Graha Ilmu.

Paula Krisanty et al., 2013, Asuhan Keperawatan Gawat Darurat, Jakarta, Trans Info Media.

Soekidjo Notoatmodjo, 2010, Etika dan Hukum Kesehatan, Jakarta, Rineka Cipta.

Setiawan, 2010, Kumpulan Naskah Etika Kebidanan \& Hukum Kesehatan, Jakarta, 
Trans Info Media.

Syahrizal Abbas, 2011, Mediasi Dalam Hukum Syariah, Hukum Adat, \& Hukum Nasional, Jakarta, Kencana

Umar Fahmi Ahmadi, 2008, Horision Baru Kesehatan Masyarakat Di Indonesia, Jakarta, Rineka Cipta.

H. Zainudin Ali, 2011, Metode Penelitian Hukum, Jakarta, Sinar Grafika, Kitab Undang-Undang Hukum Perdata Undang-Undang Nomor 36 Tahun 2009 Tentang Kesehatan. Undang-Undang Nomor 29 Tahun 2004 Tentang Praktek Kedokteran. Undang-Undang Nomor36 Tahun 2014 Tentang Tenaga Kesehatan.

Undang-Undang Nomor 44 Tahun 2009 Rumah Sakit.

Peraturan Menteri Kesehatan No. 290 Tahun 2008 Tentang Persetujuan Tindakan Kedokteran.

Peraturan Menteri Kesehatan No. 269 Tahun 2008 Tentang rekam medis.

Peraturan Konsil Kedokteran Nomor 2 tahun 2011 Tentang Tata Cara Penanganan Kasus Dugaan Pelanggaran Disiplin Dokter Dan Dokter Gigi. 